\title{
Rationale for key elements of Sino-American collaboration in clinical research
}

\author{
Robert M Califf \\ From 2012 Sino-American Symposium on Clinical and Translational Medicine (SAS-CTM) \\ Shanghai, China. 27-29 June 2012
}

When new scientific discoveries are properly evaluated within the translational research continuum and definitive evidence is generated regarding the balance of benefits and risks associated with therapeutic interventions, dramatic health improvements are seen both for individuals and populations. Until recently, however, technological limitations dictated that definitive evidence could be generated for only a fraction of interventions under development, because clinical investigation was limited by geography and access to expertise. Today, less than $15 \%$ of major medical decisions are informed by high-quality evidence [1]. Furthermore, increasing knowledge about the roles played by genetics and practice environments demonstrates that we must develop multinational studies to generate evidence relevant to particular biological and cultural contexts [2]. It is now time to begin to plan for a global learning health system.

Modern informatics and information technology have enabled the sharing of research data without regard to geographic boundaries. These new capabilities expand the concept of human biomedical research from an activity conducted in a limited number of specialized centers to a global activity accessible to all patient populations and qualified practitioners [3]. With appropriate informatics support, shared protocols, and facilitative cultural elements, common diseases can be studied on a larger scale and clinical trials in rare diseases will be able to accrue adequate sample sizes, enabling valid inferences to be drawn. In essence, the limits on knowledge generation will henceforth be determined by two key factors: (1) the number of qualified individuals in the clinical and translational research workforce and (2) the degree to which regulatory and funding sources encourage broad-scale collaboration.

Correspondence: robert.califf@duke.edu

Duke Translational Medicine Institute, Duke University, Durham, NC 27710, USA

\section{( ) Biomed Central}

(c) 2012 Califf; licensee BioMed Central Ltd. This is an Open Access article distributed under the terms of the Creative Commons Attribution License (http://creativecommons.org/licenses/by/2.0), which permits unrestricted use, distribution, and reproduction in any medium, provided the original work is properly cited.
Table 1 Key programs for clinical \& translational research

Clinical research training

Epidemiology and global health

Biostatistics

Medical informatics

Health sector management

Examples of therapeutic areas where progress could be accelerated include diabetes (which affects global populations in large numbers), congenital heart disease (which affects $1 \%$ of all global populations) and Pompe disease (a rare disease with a new effective therapy). In each case, collaborative studies between China and the United States-two of the world's largest funders of biomedical research-could provide the example to stimulate similar activity on a global scale.

We propose that five key programs specific to clinical and translational research [4] (Table 1) will need to train and educate a vast workforce over the coming decade in order to capitalize on these technological advances.

Published: 17 October 2012

\section{References}

1. Tricoci P, Allen JM, Kramer JM, Califf RM, Smith SC Jr: Scientific evidence underlying the ACC/AHA clinical practice guidelines. JAMA 2009, 301:831-841, Erratum in: JAMA 2009, 301:1544.

2. Califf RM, Zarin DA, Kramer JM, Sherman RE, Aberle LH, Tasneem A: Characteristics of clinical trials registered in ClinicalTrials.gov, 2007-2010. JAMA 2012, 307:1838-1847.

3. Dzau VJ, Ackerly DC, Sutton-Wallace P, Merson MH, Williams RS, Krishnan KR, Taber RC, Califf RM: The role of academic health science systems in the transformation of medicine. Lancet 2010, 375:949-953.

4. CMS Innovation: Health Care Innovation Awards: Project Profiles - Duke University.[http://innovation.cms.gov/initiatives/innovation-awards/projectprofiles.html]. 
doi:10.1186/1479-5876-10-S2-A4

Cite this article as: Califf: Rationale for key elements of Sino-American collaboration in clinical research. Journal of Translational Medicine 2012 10(Suppl 2):A4.

Submit your next manuscript to BioMed Central and take full advantage of:

- Convenient online submission

- Thorough peer review

- No space constraints or color figure charges

- Immediate publication on acceptance

- Inclusion in PubMed, CAS, Scopus and Google Scholar

- Research which is freely available for redistribution

Submit your manuscript at www.biomedcentral.com/submit

() BioMed Central 